\title{
The Emotional Intelligence and Pedagogic Competence on Self-Efficacy and Teacher Performance
}

\author{
Taufiqqinnoor *, Suhaimi, Karyono Ibnu Ahmad \\ Master Program of Education Management, Universitas Lambung Mangkurat, Banjarmasin 70123, \\ Indonesia
}

\author{
Article history: \\ Submission October 2020 \\ Revised February 2021 \\ Accepted March 2021 \\ ${ }^{*}$ Corresponding author: \\ E-mail: abiramzy@gmail.com
}

\begin{abstract}
Teacher's performance is one of the determinants of any educational effort's success to the point of the Indonesian national education system's success. Because teachers are the ones who conduct the teaching and learning process. Theoretically, some factors influence the performance of a teacher. Therefore, this study aims to describe and analyze emotional intelligence and pedagogical competence on self-efficacy and teacher performance in the school environment. This research was classified into a correlational study with path analysis using a research sample of 155 teachers. The data of the study were collected using questionnaires. Then, the data obtained from the questionnaires were analyzed through multiple regression methods. The results show that emotional intelligence, competence pedagogy was included in the medium category. In contrast, self-efficacy was included in the high category, and teacher performance was in a good category. The result of this study can be used by the schools and stakeholders in designing a program or activities to improve teachers' performance. In designing those activities, the schools and stakeholders should pay attention to the variables above, since this study reveals that those variables influence teachers' performance.
\end{abstract}

Keywords: Emotional intelligence, pedagogic competence, self-efficacy, teacher performance

\section{Introduction}

The quality of education has a vital role in the development of a country. By having a good quality education, a country will be able to have a quality workforce. Furthermore, with the availability of a quality workforce, labor productivity will also increase. This increase in productivity will certainly be the capital for economic growth and social welfare. Thus, the provision of quality education is a must for a country that wants to become a developed country. The quality of education is influenced by several factors. However, the main factor that determines the quality of education is the quality of the teachers.

This is because the teacher is the person who is responsible for carrying out the planning, implementation, and evaluation of learning processes to achieve the planned learning objectives. Therefore, the quality of teachers will affect the outcome of an educa-

How to cite:

Taufiqqinnoor. (2021). The emotional intelligence and pedagogic competence on self-efficacy and teacher performance. Journal of K6 Education and Management, 4 (1), 1 - 10. doi: 10.11594/jk6em.04.01.01 
tional process - the better the quality of teachers, the better the quality of education and the resulting output.

The quality of a teacher will be reflected in the teacher's performance. Teachers who have good quality, of course, will automatically show good performance and vice versa. Therefore, teacher performance is a benchmark used to determine a national education system's success. Teachers' performance in the classroom will influence the students' learning process (Murati, 2015; Nagoba \& Mantri, 2015). It means that if the teachers' performance is good, the students' achievement will be good. When the teachers are motivated to teach, it will also make the students feel motivated to join the class and get involved in the teaching and learning process (Banda \& Mutambo, 2016). In other words, teachers' performance will influence the school's effectiveness in conducting the teaching and learning process.

Indonesian national education shapes the whole human being, a man of character and a man of intelligence (Suriansyah, Aslamiah, \& Amelia, 2019). It means that education is not only aimed at making students smart academically, but education must also be able to form students who have good character. Therefore, a teacher's responsibility in Indonesia is not only to teach students about the subject matter being taught but also to provide character education.

People believe that teachers are the one that can influence the students' character. It is because teachers are role models for their students. It means that students will imitate their teachers' behavior (Martino, 2009; Narinasamy \& Logeswaran, 2015). Some studies also found that teachers' behavior will influence students' achievement and the students' characters (Haryanto \& Akhirin, 2018; Kamaruddin, 2012; Mehdipour \& Balaramulu, 2013; Pala, 2011; Alpiyanto, Hamda, \& Dalle, 2012). Teachers' character and behavior also influence students' academic achievement (Sanda, 2013). Since teachers have a crucial role in assisting the students in getting a good academic achievement and possessing good character, it shows that teachers have a great role in the education system (Mahini et al., 2012); Haghan, 2012; Al-Rowais, 2015; Vandenberghe, 1984). So, with such a vital role, it is hoped that teachers will actually have good performance. Because only with good performance can this crucial role be realized.

According to Supriyono (2010) defines performance as a result achieved by performing the tasks assigned to him based on talent, experience, patience, and time. Teachers' performance will be influenced by the four competencies that a teacher should have. Those competencies are professional, pedagogical competencies, personality competences, and social competences (Kepres, 2003). The pedagogical competencies are significantly related to performance. A similar opinion is also stated by Gesawasari et al. (2017) that teachers' competence in teaching will mainly influence their performance. It is because the main job is teaching (Nabila, 2016; Afalla \& Fabelico, 2020). Furthermore, teachers' knowledge of the subject matter they teach also influences the instruction (Welukiamba et al., 2017).

However, the fact that teachers' performance problems are still not optimal. Common issues in teachers' performance include: the teachers are not confident of themselves, are not bitter in the task, are not brave to take risks, make the device teach just copy-paste, are not using electronic media, performing tasks only limited to fulfilling obligations, not being able to recognize self-skills, not being able to control self-emotions, not being able to motivate themselves, and not being able to recognize other people's emotions (Soslau, 2017).

The teacher's performance and results are determined by psychological factors. Bandura (Luthans, 2005) presents performance satisfaction as influenced by one's efficiency. According to Warsito's research (2004), it was found that a person with high self-efficacy will give all the ability he has to achieve what he wants. With a high self-efficacy, people will do their best every time they do their job (Çetin \& Aşkun, 2017). In other words, the ones who got high self-efficacy normally have 
a high motivation to work (Anwar \& Madhakomal, 2017). According to Mok \& Moore (2019) also specifically stated that teachers' self-efficacy could help students improve their achievement.

According to Mathis and Jackson (2001) describe the performance as influenced by ability. According to Kartono (1996), psychologists are related to emotional aspects. Furthermore. Suriansyah, Aslamiah, and Amelia (2019) explain emotional intelligence has a significant impact on performance. Those who have emotional intelligence can motivate themselves to perform better (Suhaimi, 2018; Alam et al., 2020). Therefore, this study finds out the relationship between emotional intelligence, pedagogical competence, and self-efficacy against teacher performance from the problems explained above. It is hoped that this research will later provide information that can be used by schools and other policymakers to improve teachers' performance. Given the significant role of teachers and teacher, performance will affect the quality of education. The information generated from this research can be considered in determining activities that help teachers improve their performance.

\section{Material and Methods}

This research is a correlational study using path analysis. Arikunto (2019) explains that this method is used to determine the relationship or influence between two or more variables. Gunawan (2016) further states that the path analysis model is used to analyze the pattern of relationships between variables and to determine the direct or indirect effect of a set of independent (exogenous) variables on the dependent (endogenous) variable (Arikunto, 2019). The research instrument used was a closed questionnaire, which included giving several answers that the respondents could choose from. There are four questionnaires used in this study. The four questionnaires were used to measure each of the variables studied in this study.

The variables used include Emotional Intelligence (X1), Pedagogic Competence (X2), Self-Efficacy (Z), and Teacher Performance
(Y). The sample used in this study were 155 teachers at Madrasah Aliyah Banjarmasin City. The data obtained were then analyzed using SPSS version 23.

\section{Results and Discussion}

The study variables are described in the form of scores with the highest score is five and the lowest is 1 . The tabulated data from each research variable is presented as follows Distribution of scores for emotional intelligence variables, Distribution of scores for pedagogic competence variables, Distribution of scores for self-efficacy variables, and Distribution of scores performance variable.

The average value obtained for teacher performance is 3.09, which is categorized as high, with the Learning Planning sub-variable obtaining the highest average value of 3.46 , with many contributing factors in formulating learning objectives in learning planning according to the curriculum/ syllabus and paying attention to the characteristics of students and the lowest sub variable of the learning assessment with an average of 2.75 with less role utilization of various assessment results to provide feedback for students about the progress of learning and the material of drafting further learning plans may be due to the lack of variety of methods and strategies and instruments that correspond to the learning design.

Before performing inferential statistical analysis using path analysis, the researcher conducted several prerequisite tests: the normality test, linearity test, and homogeneity test. The prerequisite test is carried out to ascertain whether the data analysis can be performed using a parametric inferential statistical test or must use a non-parametric inferential statistical test. The following is an explanation of each of the prerequisite tests carried out in this study.

\section{Data normality test results}

This test was conducted to determine whether the dependent and independent variables have normal distributions or not. This study used the Kolmogorov-Smirnov One sample method with Asymp Sig 2-tailed such 
that if the significance is less than 0.05 , the data is not normally distributed and vice versa. The results obtained are presented in Table 1. Table 1 shows the significance value (Asymp Sig 2-Tailed) for Emotional Intelligence (X1) was 0.718, Pedagogic Competence

Table 1 . Normality test results
(X2) was 0.684, Self-Efficacy (Z) was 0.714, and Teacher Performance variable $(Y)$ was 0.770 . Since all the significant values are more than 0.05 , the data in all the variables are normally distributed.

One-Sample Kolmogorov-Smirnov Test

$\begin{array}{rrrr}\begin{array}{r}\text { Emotional Intel- Pedagogic } \\ \text { ligence }(\mathrm{X} 1) \\ \text { Compe- } \\ \text { tence }(\mathrm{X} 2)\end{array} & \begin{array}{r}\text { Self-Efficacy } \\ (\mathrm{Z})\end{array} & \begin{array}{r}\text { Teacher Per- } \\ \text { formance } \\ (\mathrm{Y})\end{array} \\ 12155 & 155 & 155 & 155 \\ 121.44 & 121.47 & 51.66 & 58.39 \\ 6.418 & 6.423 & 6.066 & 3.292 \\ & & & .079 \\ .058 & .056 & .053 & .065 \\ .048 & .050 & .053 & -.079 \\ -.058 & -.056 & -.034 & .664 \\ .696 & .716 & .698 & .770 \\ .718 & .684 & .714 & \end{array}$

a. Test distribution is Normal.

b. Calculated from data.

Source: SPSS Output 23, 2020.

Furthermore, the regression analysis through Self-Efficacy (Z). The value of the showed the indirect influence of Emotional path coefficient is shown in Figure 1.

Intelligence (X1) on Teacher Performance (Y)

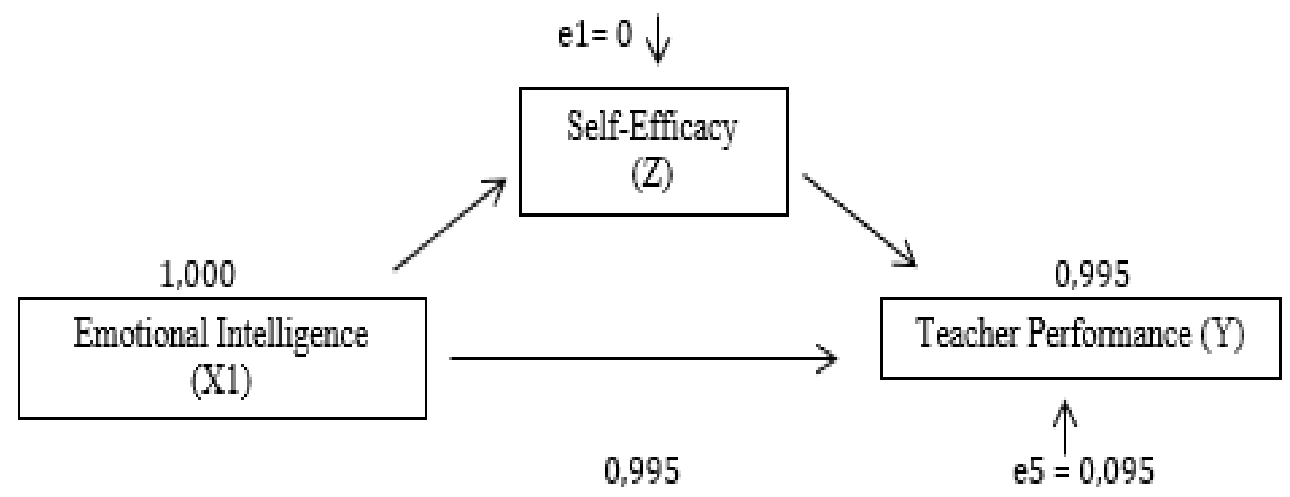

Figure 1. Trajectory Model of Relationships between X1 and Y through Z 


\section{Data linearity test results}

The linearity test was conducted to determine whether there is a linear relationship between the research variables. SPSS was used in this study to test for linearity at a significance level of 0.05 . However, two variables are linearly related if the significance value is $<0.05$ (Arikunto, 2019). The linearity test result for the variables in this study can be seen in Table 2:

Table 2. Linearity test results from relationship emotional intelligence (X1), Pedagogic competence $(\mathrm{X} 2)$, Self-efficacy $(\mathrm{Z})$ and Teacher performance $(\mathrm{Y})$

\begin{tabular}{cccc}
\hline No. & Variable & Linearity & Information \\
\hline 1. & $\mathrm{X} 1$ dan $\mathrm{d}$ & 0,000 & Linear \\
2. & $\mathrm{X} 2 \operatorname{dan} \mathrm{Z}$ & 0,000 & Linear \\
3. & $\mathrm{X} 1 \operatorname{dan} \mathrm{Y}$ & 0,000 & Linear \\
4. & $\mathrm{X} 2 \operatorname{dan} \mathrm{Y}$ & 0,008 & Linear \\
5. & $\mathrm{Z}$ dan $\mathrm{Y}$ & 0,000 & Linear \\
\hline
\end{tabular}

Source: Data processed from research results, 2020

Table 2 shows the significance value obtained to be $0,000<0.05$, and this means the relationship between Emotional Intelligence (X1), Pedagogic Competence (X2), Self-Efficacy $(\mathrm{Z})$, and Teacher Performance $(\mathrm{Y})$ variables is linear. Thus, the prerequisite test to the homogeneity test.

\section{Homogeneity test results}

The homogeneity test is carried out to determine whether the data in variables $X$ and $\mathrm{Y}$ are homogeneous or not. Homogeneous means that the variables studied have the same variance distribution. The homogeneity test results are shown in Table 3.

Table 3. Homogeneity test results

\begin{tabular}{cccc}
\hline No. & Variable & P-value / sig & Information \\
\hline 1. & $\mathrm{X} 1$ dan $\mathrm{d}$ & 0,977 & Homogenous \\
2. & $\mathrm{X} 2$ dan $\mathrm{C}$ & 0.988 & Homogenous \\
3. & $\mathrm{X} 1$ dan $\mathrm{Y}$ & 0.693 & Homogenous \\
4. & $\mathrm{X} 2$ dan $\mathrm{Y}$ & 0.660 & Homogenous \\
5. & $\mathrm{Z}$ dan $\mathrm{Y}$ & 0.672 & Homogenous \\
\hline
\end{tabular}

Source: SPSS Output 23, 2020

Table 3 shows the total $p$-value $>0.05$, and this means the data were obtained from a homogeneous sample. After all the prerequisite tests were carried out, namely the normality, linearity, and homogeneity tests, which showed that the data met the requirements, the analysis was continued with the path analysis test.

The analysis of the data provided is summarized in the following image. 


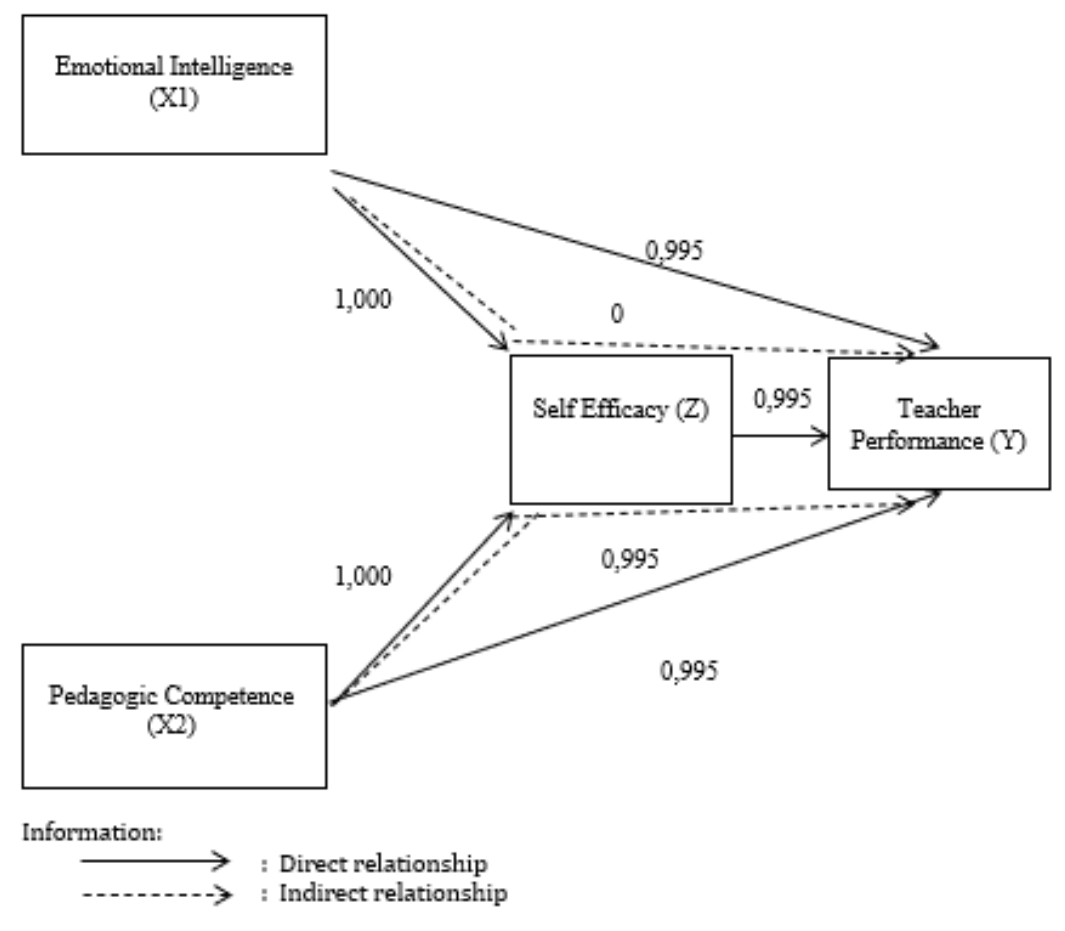

Figure 2. Analysis of the Relationship Between the Emotional Intelligence (X1), Pedagogic Competence $(X 2)$, Self-Efficacy $(Z)$ and Teacher Performance $(Y)$

\section{Hypothesis testing}

The hypothesis developed to determine the indirect relationship between emotional intelligence and teacher performance through self-efficacy:

$\mathrm{HO}=$ there is no indirect relationship between emotional intelligence and teacher performance through self-efficacy.

$\mathrm{Ha}=$ there is an indirect relationship between emotional intelligence and teacher performance through self-efficacy.

The criterion for acceptance or rejection of the hypothesis is if the $t$ table value's significance value for $n=155, H 0$ is rejected and vice versa.

The indirect relationship between the Emotional Intelligence variable (X1) and teacher performance $(Y)$ through Self Efficacy $(\mathrm{Z})$ is obtained by multiplying the path coefficient of the direct relationship variable $\mathrm{X} 1$ to
Z (P1) with the direct relationship path coefficient of variables $Z$ to $Y$ (P5), namely Mathematically $1,000 \times 0.995=0.995$. This means that there is an indirect positive relationship between the Emotional Intelligence variable (X1) and the teacher performance variable (Y) through Self Efficacy (Z) of 0.995.

The mediation was tested by multiplying P1 $\times$ P5 $=0.995$, while the significance was calculated using the following equation:

Calculate the standard error of the indirect coefficient (Se15)

$$
\begin{aligned}
& \text { Se15 }=\sqrt{P_{5}^{2} \cdot S e_{1}^{2}+P_{1}^{2} \cdot S e_{5}^{2}+S e_{5}^{2} \cdot S e_{1}^{2}} \\
& =\sqrt{0,352743} \\
& =0,594
\end{aligned}
$$

From the Se15 results, the mediation relationship was calculated as follows:

$$
t=\frac{P_{15}}{S e_{15}}=\frac{0,995}{0,594}=1,675
$$

The value obtained is presented in Table 4 below. 
Taufiqqinnoor, 2021 / The emotional intelligence and pedagogic competence on self-efficacy and teacher performance

Table 4. Mediation variable relationship test results (X1 to Y through Z)

\begin{tabular}{ccccc}
\hline Variable & Indirect Relations & Sindirect effect & $\mathrm{T}$ & Information \\
\hline $\mathrm{X} 1$ to $\mathrm{Y}$ through $\mathrm{Z}$ & 0,995 & 0,594 & 1,675 & Significant \\
\hline
\end{tabular}

Source: Calculation Results, 2020

Table 4 shows that overally the Emotional Intelligence variable has a $t$ count greater than $\mathrm{t}$ table, with a significance level of 0.05 , which means that $\mathrm{H} 0$ is rejected. Therefore, there is an indirect relationship between Emotional Intelligence and teacher performance through Self Efficacy.

Systematically, the factors that link the professional performance of teachers are grouped into four components. First, the input of limited raw elements includes planning learning according to the curriculum/syllabus and paying attention to students' characteristics. Second, the instrumental component's input includes the ability to recognize Self-Emotions, such as the correct fear/nervousness management factor at work. Third, the instrumental component includes the ability to master student characteristics such as talents, interests, and stages of student development. The fourth involves the level/magnitude component (level of difficulty of the task) such as liking, accepting, planning, and carrying out teaching assignments well.

The results of the study are supported by the results of the previous studies. Some previous studies have proven that teachers' selfefficacy influences teachers' performance, especially in the teaching and learning. The study conducted by Achurraa \& Villardón (2012) found that teachers' self-efficacy influences the students' learning. A similar study was also conducted by Shahzad \& Naureen (2017), who conducted the study by involving sixty teachers and a hundred students of secondary schools in Chiltan Town of Quetta city. They found that teachers' self-efficacy affects students' achievement positively. Besides, Cansoy et al. (2018) also found that selfefficacy is a strong moderator for the students' achievement. Thus, teachers' self-efficacy can be a determinant for teachers' performance. It is because teachers' performance

can be seen from the students' achievement (Széll, 2013). Another study that proves selfefficacy positively influences teachers' performance is also conducted by Mohamed \& Yunus (2017).

Emotional intelligence, also found by some researchers, has a positive effect on teachers' performance. Mehmood, Qasim, \& Azam (2013) found that lecturers' emotional intelligence influences their performance at the university level. The study conducted by Arthi \& Sumathi (2016) at private schools that involved 113 teachers also found that teachers' emotional intelligence has a significant effect on teachers' performance. Besides, they also found that gender also influences the effect of emotional intelligence on teachers' performance. Another study that confirms emotional intelligence influences teachers' performance is done by Kaur, Shri, \& Mital (2019). They found that the lecturers' performance in higher education level is influenced by their emotional intelligence. Other studies that support that finding are the studies conducted by Soanes \& Sungoh (2019), who found that emotional intelligence positively affects teachers' performance.

Some studies also support that pedagogical competence has a positive effect on teachers' performance. Teachers' competency in implementing teaching strategies influence their performance and students' achievement. Teachers' pedagogic knowledge and skills positively affect students' academic achievement (Dhillon, 2014). Teachers' pedagogical knowledge and content knowledge will influence the teaching and learning process's effectiveness. A similar finding is also found by Block, Crochet, Jones, \& Papa (2013). They found that teachers' effectiveness in conducting the teaching and learning process influences the students' learning achievement. Another study that found teachers' teaching competence that influences their 
performance and the students' achievement was also conducted by Arifah \& Prijambodo (2014).

From the explanation above, it can be seen that previous research has identified that selfefficacy, emotional intelligence, and pedagogical competence have a positive and significant effect directly on teacher performance. Each of these variables has a direct impact on teacher performance. So, it can be said that self-efficacy has a positive and significant effect on teacher performance and emotional competence and pedagogical competence, which have a direct, positive, and significant effect on teacher performance.

Furthermore, this study enriches previous studies' results by proving that emotional competence and pedagogical competence affect teacher performance directly and indirectly. Both emotional and pedagogical competence also have an indirect effect through self-efficacy.

This means that with different levels of self-efficacy, the impact of emotional competence and pedagogical competence will also be different. The higher the self-efficacy of a teacher, the better the pedagogical and emotional competencies will be. So, it can be said that self-efficacy is a moderator variable that is important to pay attention to to improve teacher performance. Research, which also found that self-efficacy is a vital moderator variable in performance, was also conducted by Abd-Elmotaleb \& Saha (2013). Therefore, based on the results of this study, in addition to increasing emotional intelligence and pedagogic competence, increasing teacher self-efficacy must be done to improve teacher performance at Madrasah Aliyah Banjarmasin

\section{Conclusion and Recommendation}

This result can be concluded that emotional intelligence has a positive and significant relationship with performance through teachers' self-efficacy at Madrasah Aliyah Banjarmasin City. Emotional Intelligence, Pedagogical Competency is in the moderate category, while self-efficacy is in High and Teacher Performance in the good category. Therefore, it is recommended that the schools and the stakeholders conduct activities that can improve teachers' self-efficacy, emotional intelligence, and pedagogical competence. Because if the teachers' self-efficacy, emotional intelligence, and pedagogical competence are high, it will positively impact their performance and the students' achievement. Besides, teachers should also develop the ability to plan learning activities more effectively by using strategies that are oriented towards each student's characteristics and using various methods and techniques and instruments that vary in learning assessment.

Since this study is limited to Madrasah Aliyah Banjarmasin City, a further study is needed by involving more teachers from various schools. It is done to have better results that can be generalized into a bigger population so that the results of the study can be used by more parties to improve the teachers' performance.

\section{Acknowledgment}

The authors say thanks to Universitas Lambung Mangkurat for supporting this research.

\section{References}

Abd-Elmotaleb, M., \& Saha, S. K. (2013). The Role of Academic Self-efficacy as a mediator variable between perceived academic climate and academic performance. Journal of Education and Learning, 2(3), 118-129.

Achurraa, C., \& Villardón, L. (2012). Teacher' selfefficacy and student learning. The European Journal of Social \& Behavioural Sciences, 2(17), 367-383. doi:http://dx.doi.org/10.15405/FutureAcademy/ejs bs(2301-2218).2012.2.17

Afalla, B. T., \& Fabelico, F. L. (2020). Pre-service teachers' pedagogical competence and teaching efficiency. Journal of Critical Reviews, 7(11), 223-228. doi:http://dx.doi.org/10.31838/jcr.07.11.36

Alam, F., Yifei, L., Raza, M., \& Khan, K. (2020). The impact of leader's emotional intelligence on employee organizational behavior: Mediating role of employee motivation. European Academic Research, 7(10), 5127-5154.

Alpiyanto, Hamda, S., \& Dalle, J. (2012). The role of teachers in the formation of student characters through local visition. Prosiding Temu Ilmiah 
Nasional Guru IV (pp. 74-83). Jakarta: Open University.

Al-Rowais, A. S. (2015). Roles of a teacher in colleges of education. International Journal of Technology and Inclusive Education, 4(2), 654-660.

Anwar, J., \& Madhakomal, R. (2017). Self-efficacy: Staircase to the intention of employees' turningover. International Journal of Human Capital Management, $1(1)$, 23-32. doi:https://doi.org/10.21009/IJHCM.01.01.03

Arifah, N., \& Prijambodo, V. L. (2014). The teacher's roles in teaching english for specific purposesto nursing program students. Magister Scientiae, 35, 132-148.

Arikunto, S. (2019). Research procedure: A practical approach. Jakarta: Rineka Cipta.

Arthi, R., \& Sumathi, G. (2016). Emotional intelligence and job performance among school teachers - an empirical approach. Sona Global Management Review I, 10(3), 13-25.

Banda, M., \& Mutambo, P. P. (2016). Sociological perspective of the role of the teacher in the 21st century. International Journal of Humanities Social Sciences and Education, 3(1), 162-175.

Block, E., Crochet, F., Jones, L., \& Papa, T. (2013). The importance of teacher's effectiveness. Creative education, 3 ,

1164-1172. doi:http://dx.doi.org/10.4236/ce.2012.326173

Cansoy, R., Polatcan, M., \& Parlar, H. (2018). Research on teacher self-efficacy in Turkey: 2000-2017. Journal of Education, 8(4), 133-145. doi:https://doi.org/10.5430/wje.v8n4p133

Çetin, F., \& Aşkun, D. (2017). The effect of occupational self-efficacy on work performancethrough intrinsic work motivation. Management Research Review, 1-16. doi:https://doi.org/10.1108/MRR-032017-0062

Dhillon, C. K. (2014). Iidentifying essential teaching skills. Scholarly Research Journal for Interdisciplinary Studies, 2(8), 1613-1620.

Gewasari, M., Manullang, B., \& Sibuea, A. M. (2017). The determinant factors that effect teacher performance of public senior high school in Deli Serdang District. OSR Journal of Research $\mathcal{E}$ Method in Education, 7(1), 12-21. doi:10.9790/73880701041221

Gibson, J., Ivancevich, J., \& Junior, D. (2008). Organisasi, Perilaku, Struktur, dan Proses. Jakarta: Binapura Aksara Publisher.
Haryanto, \& Akhirin. (2018). Building students' character through integrated teaching learning activities at madrassa. Internationalization of Islamic Higher Education Institutions Toward Global Competitiveness, (pp. 518-526). Semarang.

Kamaruddin, S. A. (2012). Character Education and Students Social Behavior. Journal of Education and Learning, 6(4), 223-230.

Kartono, K. (1996). Psikologi Umum. Bandung: Mandar Maju.

Kaur, I., Shri, C., \& Mital, K. M. (2019). The role of emotional intelligence competencies in effective teaching and teacher's performance in higher education. Higher Education for the Future, 6(2), 188-206. doi:https://doi.org/10.1177/2347631119840542

Keiler, L. S. (2018). Teachers' roles and identities in student-centered classrooms. International Journal of Stem Education, 5(1), 1-10. doi:10.1186/s40594018-0131-6

Kepres. (2003). Undang-Undang Republik Indonesia Nomor 20 Tahun 2003 Tentang Sistem Pendidikan Nasional. Jakarta.

Luthans, F. (2005). Perilaku Organisasi Edisi Sepuluh. Yogyakarta: Andi.

Mahini, F., Forushan, Z. J.-A., \& Haghan, F. (2012). The importance of teacher's role in technology-based education. Procedia - Social and Behavioral Sciences, 46, 1614-1618.

Martino, W. (2009). Teachers as role models. In L. Saha, \& A. Dworkin, International Handbook of Research on Teachers and Teaching (pp. 755-768). Boston: Springer. doi:https://doi.org/10.1007/978-0-38773317-3_47

Mathis \& Jackson. (2001). Manajemen Sumber Daya Manusia Jilid 2. Jakarta: Salemba Empat.

Mehdipour, Y., \& Balaramulu, D. (2013). The influence of teacher's behavioron thestudent's selfregulation. IOSR Journal of Research \& Method in Education, 1(6), 65-71.

Mehmood, T., Qasim, S., \& Azam, R. (2013). Impact of emotional intelligence on theperformance of university teachers. International Journal of Humanities and Social Science, 3(18), 300-307.

Mohamed, W. H., \& Yunus, J. N. (2017). Self-Efficacy and Academic Performance of Secondary Schools Students in Perak: An Exploratory Outlook. International Journal of Academic Research in Progressive Education and Development, 6(3), 41-55. doi:http://dx.doi.org/10.6007/IJARPED/v6-i3/3081 
Mok, M. M., \& Moore, P. J. (2019). Teachers \& selfefficacy. Educational Psychology, 39(1), 1-3. doi:https://doi.org/10.1080/01443410.2019.1567070

Murati, R. (2015). The role of the teacher in the educational process. The Online Journal of New Horizons in Education, 5(2), 75-78.

Nabila, H. (2016). The influence of pedagogic competence andprofessional competence to performance ofteachers social studies in trowulan district. International Conference on Ethics of Business, Economics, and Social Science (pp. 556565). Yogyakarta: Yogyakarta State University.

Nagoba, B. S., \& Mantri, S. B. (2015). Role of teachers in quality enhancement in higher education. Journal of Krishna Institute of Medical Sciences University, 4(1), 177-182.

Naqvi, I. H., Iqbal, M., \& Akhtar, S. N. (2016). The relationship between emotional intelligence and performance of secondary school teachers. Bulletin of Education and Research, 38(1), 209-224.

Narinasamy, I., \& Logeswaran, A. K. (2015). Teacher as moral model - Are we caring enough? World Journal of Education, 5(6), 1-13. doi: http://dx.doi.org/10.5430/wje.v5n6p1

Özgene, M., \& Mert, P. (2019). The role of teacher performance in school effectiveness. International Journal of Education Technology and Scientific Researches, 4(10), 417-434. doi: 10.35826/ijets

Pala, A. (2011). The need for character education. International Journal of Social Sciences and Humanity Studies, 3(2), 23-32.

Sanda, S. (2013). Influence ofteacher characteristics on students' academic achievementamong senior high schools in ogan komering ulu. Journal of English and Education, 7(2), 42-57.

Shahzad, K., \& Naureen, S. (2017). Impact of teacher self-efficacy on secondary school students' academic achievement. Journal of Education and Educational Development, 4(1), 48-72.
Soanes, D. G., \& Sungoh, S. M. (2019). Influence of emotional intelligence on teacher effectiveness of science teachers. Psychology, 10, 1819-1831. doi:10.4236/psych.2019.1013118

Soslau, E. (2017). Problems in student teaching. The Journal of Teaching and Learning, 11(1), 20-28. doi:http://dx.doi.org/10.22329/jtl.v11i1.4612

Suhaimi, W. (2018). Hubungan antara superpisi kepala sekolah dan Motivasi Berprestasi dengan Kinerja Guru SD Negeri di Kecamatan Tanjung Kabupaten Tabalong. Prosiding SEMNAS PS2DMP ULM. 3, pp. 1-6. Banjarmasin: Program Megister Manajemen Pendidikan ULM.

Supriyono. (2010). Pengukuran Produktifitas dengan Metode Nilai Tambah. Jakarta: Direktorat Produktifitas DIRJEN Pembinaan Pelatihan dan Produktifitas DEPNAKRETRANS RI.

Suriansyah, A., Aslamiah, \& Amelia, R. (2019). Hubungan Budaya Kerja, Kecerdasan Emosional dan Organizational Citizenship Behavior (OCB) Terhadap Mengajar Kinerja Guru SD Kecamatan Banjarmasin Utara. Banjarmasin: Universitas Lambung Mangkurat.

Széll, K. (2013). Factors determining student achievement. Hungarian Educational Research Journal, 3(3), 55-66. doi:10.14413/HERJ2013.03.06.

Vandenberghe, R. (1984). Teacher's Role in educational change. Journal of In-Service Education, 11(1), 14-25. doi: https://doi.org/10.1080/0305763840110103

Warsito, H. (2004). Hubungan Efikasi Diri dengan Penyesuaian Akademik,. Jurnal Psikologi vol.14 No.2, 92-109.

WeluKiamba, E., Mutua, F., \& Mulwa, D. (2017). Influence of teacher's subject matter knowledge on students' academicachievement of kiswahili language in public secondary schools in Kathonzweni Sub-County,Kenya. Scholarly Research Journal for Humanity Science \& English Language, 6(29), 8052-8059. 